\title{
The Importance of Scientific Studies Regarding Internal Migration in Turkey
}

\author{
Dr. Ertuğrul Güreşci \\ Ahi Evran University Kırşehir/Turkey
}

\begin{abstract}
In order to put forth the economic, social and political transformation of society in a nation, its causes and its results, scientific studies regarding internal migration are needed. Such scientific studies will have effect on presenting more objective and permanent info to society on the subject of internal migration which is an important fact in terms of economic and social aspects. In the developing countries such as Turkey, one of the vital factors determining the social structure and the developments is the internal migration partaking in that country. Acting in accordance with the point of putting forth the importance of such migrations, setting forth the current situation of academic studies and scientific events regarding the internal migration in Turkey is aimed in this study. Also in the study, determining the purpose of scientific studies which will be about internal migrations in Turkey, their scope and their problems, and playing a beneficial role to all parties regarding this topic are aimed.
\end{abstract}

Keywords: Migration, internal migration, scientific event

\section{Introduction}

Migration is a fact as old as the history of humanity. For various reasons, humans abandoned the place they lived or they were forced to. Migration has been a vital factor in the hauling or birth of many civilizations and cultures (Bilgili and Weyel; 2009; Güreşci, 2011; IOM, 2013; Şenel, 1992; Park, 1928).

Migration can be put as the definition of humans abandoning their residences for various economic and social reasons. But in the definition of migration, movement from a region or a residence to another place is derived. In the definition of migration, though the distance that were taken and the amount of time are taken into account, it being a movement from a residence to another to reside is relatively essential (Çağlayan, 2006; Güreşci, 2010; National Georaph, 2005).

While ancient civilizations were abandoning their residence for vital reasons initially such as nourishment and sheltering, it can be said that in time this abandonment transformed into forced abandonments with the gained power having become exclusive. Such migrations have taken place throughout history (Güran, 2009:9-149). Yet aside from this topic which can be assessed with proofs from history, what's essentially important for migration is it having been resulted from economic and social reasons. At this point economists, sociologists, historians or other human sciences can be associated to migration studies.

Industrial revolution can be said to be the biggest change seen in the world regarding migration. Industrial revolution, starting with England in 1800 s, can be said to be the origin of migration studies. In that, industrial revolution is regarded as an era in which labor demand was born, mass and serial production was realized and rural society was started to become continuously and intensively disintegrated (Güran, 2009: 135147; Ongun, 2009: 1-14). After this process, an intensive labor flow from small residences towards big ones, from rural towards urban,initially Europa, then America and other countries took place and rural migration fact came to be. Yet at this point it should be stated that rural migration which started in Europa did not only take place in the country but gained an international characteristic. Thus America being defined as an immigrant country has something to do with the rural population in Europa becoming disintegrated.

It should be said that the delayed effect ofindustrialization periodin Europa has reflected to other countries as well. Though there were differences in the developing countries among which Turkey partakes themigrations from rural towards urban can be said to have taken place for some similar reasons. It can be said that rural migrations had the biggest part amongst the migrations from rural to urban which started in 1950s in Turkey. Yet it should be stated that the rural migrations in Turkey had some differences from the rural migrations in Europa which were realizedalongside with the industrial revolution. These;

1. Took place in a shorter amount of time compared to Europa's. This gave birth to urban problems.

2. Took effect intensively not only in parallel with the industrialization, but also resulted from the problems of the rural between the relationships of soil-human.

3. Generally took place from rural to urban.

4. Not as much abroad as the rural migrations in Europa, widely took place domestically. 
5. Such migrations were affected mostly from the economic and social developments in Europa, although in Turkey certain political reasons had effect in these as well.

As a result it can be stated that the rural migration in Turkey is a most vital social fact with its reasons and results (Çelik, 2007; Gürbüz and Karabulut, 2008; Güreşci, 2012; Özdemir, 2012; Sağlam, 2006).Thus, reasons and results of an important fact need to be understood well enough. And the best way to do this is to carry out scientific studies in this regard and to examine the topic within the frame of objective and scientific disciplines.

\section{Scientific Events Which Were Conducted In Turkeyregarding Internal Migration}

Scientific studies start with curiosity and questions, and then go on with the study and research to find the answer of these questions. But the wondered topic having importance for the humanity is rather of importance to the topic as well. In the field of social sciences, a topic having importance in a social regard or the effect of which on human behaviors being notable may also be taken into account (Düztepe, 2004; Özdamar vd, 1999). Like migration, explanation of a topic concerns numerous science branches whether it's closely related or not.In that, the migration fact deals with the movement of a human or humans from a place to another. Some questions which can be wondered or asked at this point might be related to $\mathrm{W}$ and $\mathrm{H}$ questions; why, how, when, to where or whom carried out the migration. In using these or similar questions regarding migration in a scientific study, what should be considered also is that the migration may also have its positive and negative effects.

In the world, especially, mass sorrowfulness and urbanity which started with the industrial revolution caused the rural population to disintegrate and move towards urban. The importance of this process is relatively big in the history of Europa. That being said, human movements play a vital role in the creation of states and systems or in the sustainment and development of the existence of civilizations. For this reason; industrialization and rural social values may be though alongside with the history of migration and its reasons in the scientific studies in Europa regarding migration (Ashraful and Khalil, 2012; Güreşci, 2009; Kundu, 2009; Smith, 2009).

Migration's relatively big importance doesn't just apply to Europa but also applies to other developed or developing countries. Migrations from rural to urban of developing countries such as Turkey are also very worth mentioning. Along with its reasons and results, it is known that migrations from rural to urban increased in a manner worth mentioning especially after 1950s in Turkey. Thereby, after those years, researches with scientific content regarding internal migration can be said to have been conducted in Turkey (Gürbüz and Karabulut, 2008). Rural migrations were seen as problems in Turkey in periods which started subsequently after 1950s and when rural society gradually began to give signals of disintegration. Thus, internal migration studies were not worth mentioning in these years (Yavuz vd, 2004). This topic started to gain the attention of researchers in periods just about when rural migrations became intensive and started to take place on a high level.

It can be said that some periods are vital in the analysis of internal migration studies in Turkey. Also it can be expressed that this importance stems from the serious and mass change in the amount and direction of internal migrations (Saraçoğlu, 2012; Topbaş and Tanrı̈ver, 2008). Thus these periods can be presented with its main lines as below.

1. ${ }^{1}$ The period from the republic proclamation until 1950: This was the period in which peasant and agricultural community character, which would be taken from Ottoman Empire, existed. In this era internal migrations that are worth mentioning did not take place.

2. 1950-1980 Period: This era composes the turning point of the history of Turkey. This was the era in which multi-party system was accepted and urbanity started and day by day rural community disintegrated more and more. Migration was started to be perceived as a problem in internal migration studies.

3. 1980-2000 Period: This was the period in which foreign expansion politics of Turkey and liberalization in economics was tried to be realized. In this era, the population of the rural gained an increase both in amount and in proportion, and the topic went on as problems in the rural gained attention. This period consisted one of the most proper eras for internal migration studies.

4. 2000 Period and afterwards: This was the period in which rural migration stopped alongside with the decreasing population in the rural. For this was the period when the urban problems hit the fan more and more, topic was regarded in parallel with internal migrations and urbanity.

Scientific studies can also be conducted by various institutions or organizations initially universities.

\footnotetext{
${ }^{1}$ It can be said that some internal migrations took place in this era and these stemmed from internal security problems. But, in the study, internal migrations that were carried out due to security weren't given place.
} 


\subsection{The Importance of Scientific Studies Regarding Internal Migration}

Properties are a vital factor when explaining internal migrations, economic and social events in countries (Güreşci, 2009; Kurt, 2006). Such migrations are also important for they set forth reasons and results of the population movements between residences.

Scientific studies were conducted on migrations in Turkey and are still being conducted. Such studies can be gathered under the title external and internal migrations. And rural migration studies are regarded as internal migrations. It should be said that there are some vital shortcomings in Turkey in such studies in which reason and results regarding the topic are brought forth. Some of these,

1. They are not sufficient numerically.

2. The topic is approached by focusing on problems.

3. The topic is examined with an urbanite point-of-view.

4. There are deficiencies stemming from qualitative studies.

5. Studies on the rural are not sufficient.

6. There are deficiencies in choosing the material and method regarding the topic.

7. Conducted studies are not shared enough by the shareholders of the topic.

The purpose of this study is to bring about the aim, context and the methods of internal migration studies and their shortcomings.

\subsection{The aim of the scientific studies regarding internal migration}

The most vital aim of the studies in Turkey regarding internal migrations is to put forth why and how these migrations take place. Putting forth the relationship between reasons and results will be relatively helpful in examining the economic and social structure of the country and this structure's changes. Moreover to these, completing the shortcomings in quality and quantity aspects of such studies is expected and for this to shed light on the studies to be conducted is also awaited.

Migrations from village to urban or the ones from rural to urban are generally used in internal migration studies in Turkey. The most vital reason of this is because such migrations have increased significantly and rural-urban difference is worth mentioning. When TSI internal migration values are checked, it can be seen that from-urban-to-urban migrations are the most prevalent ones in internal migrations in Turkey (TSI, 2012). But because the migrations from a city to another don't take place between different economic and social life units, it's a fact that they are not paid much attention. Assignation, assignments or the migrations of students between cities haven't much been taken into account in scientific studies.

It's a fact that migrations from rural to urban are known to compose the most important pillar of the internal migration studies in Turkey. The most vital aim of studies on such migrations is to put forth the reasons of rural migration and to determine its urban effects. Yet Güreşçi and Yurttaş (2008) put forth the reasons of migrations, which are from rural to urban, in the studies they conducted by using the survey they executed in rural areas and they tried to explain the agricultural facts of the area not only with its present migration but also with its reasons in its tendency towards migration.

\subsection{Method and materials that are used in internal migration studies}

Internal migration studies receive the attention of all disciplines in the field of social sciences. Among these; economy, law, history, public administration, labor economics, management, geography, behavioral sciences, population sciences and also other sciences partake. Moreover, agricultural economics and statistic sciences also concern about internal migration studies. Common or different materials can also be used for every science branches in internal migration studies which can find a place for itself in such a large and comprehensive field. But it is a fact that materials that will be used in internal migration studies, center of which human or human masses and their movements consist, stem from humans and their behaviors.

Two types of material are used in internal migration studies. First is quantitative data. These data is numerical and can be used in surveys to be conducted in the field studies regarding internal migration and in the analysis and reviews of these. Again, the migration statistics and population data of TSI can be regarded also as an important quantitative source. Another data source is quantitative data. Such data can be regarded as reviews, opinions and other works concerning internal migration.

Initially quantitative data deficiency is an important obstacle in internal migration studies in Turkey. Yavuz vd. (2004) have called attention to the deficiency of quantitative researches in such studies. It is important to determine the sample mass on whom the procedure will be conducted, and to make and assess the survey which will be conducted on this mass in the data which will be compiled in the field studies. These reasons come into prominence in determining the statistical methods which will be used in the field studies, internal migration studies, making exemplification and analyses. TSI can be said to have a serious deficiency in the data used in internal migration studies. Though this was largely made up with the Address Based Population 
Registration System, it's a fact that it's still not sufficient in determining especially the reasons and the number of migration between residences.

\section{${ }^{2}$ 2.4. Internal migration studies which were conducted in Turkey}

Internal migration studies in Turkey found a place for itself in various platforms. These mostly take place within universities. It should be said that, aside to these, there are also studies which were conducted by non-university institutions, NGO and government agencies. Activities such as symposium, conference or congress in which internal migration studies conducted in Turkey take place are as follows:

1. II. National Congress of Sociology:was organized by Sociological Association at 20-22 November 1996 in Mersin and its main theme was selected as 'Society and Migration'. In the congress, aside from the opening speeches, opening notification, notification of mayors and notification of SIS; notifications of the participants from NGO and from various universities were presented in the congress under the topic titles stated below.

2. Internal Migration in Turkey: Its Problematic Areas and Symposium of Research Methods: was organized by History Foundation at 6-8 June 1997 in Bolu-Gerede.

3. Symposium of International Migration: was organized by Zeytinburnu Municipality at 8-11 August 2005. One of its main topics was established as internal migration and possible solutions.

4. IV. Cultural Studies Symposium: Internal/External/Migration and Culture: was organized by Işık University at 15-17 September 2007 in İstanbul.

5. International Migration and Women Symposium:was organized by Zeytinburnu Municipality at 01-02 August 2007.

6. Migrations from Ancient History to Today in Çanakkale: was organized by Çanakkale on Sekiz Mart University Department of History, Faculty of Science with the Culture Foundation at 18 November 2011.

7. Symposium of International Migration and Short-Film Competition:Symposium of International Migration which was themed as "Migration: the Truth of Turkey and the World" was organized by Gaziantep University with the support from Republic of Turkey Ministry of Family and Social Policy, the Ministry of Culture and Tourism, Republic of Turkey Prime Ministry Directorate of Overseas Cypriots and Related Communities, Gaziantep Governorship, Gaziantep Metropolitan Municipality and Silk Road Development Agency at 11-13 May 2012 in Gaziantep.

Aside from congress, symposium and workshops in Turkey regarding internal migrations, research and analysis reports which universities and some foundations conducted were also prepared. Most vital ones amongst these are;Turkey Migration and Internally Displaced Population Survey (TMIDPS) which was published by Hacettepe University Institute of Population Studies at 6 December 2006, migration report of theMediterranean Migration, research reports of the Migration Foundation, research report of theAccessible Life Association regarding internal migration etc.

Reports of migration research centers, which are constructed within universities alongside with the foundations and associations that do such researches, are also present. Migration research centers that were constructed within universities in Turkey are as follows.

1. Application and Research Center for Immigration Studies, İstanbul Bilgi University.

2. Migration and Politics Research Center, Hacettepe University.

3. Application and Research Center for Migration Studies, Koç University.

4. Migration Research and Application Center, Bülent Ecevit University.

5. Population and Migration Research and Application Center, Yüzüncü Yıl University.

6. Migration and Politics Research and Application Center, Gaziantep University.

Scientific studies on a regional and national scale are being conducted in research centers of universities regarding migration. Some of which are academic articles and some support various projects.

Studies relevant to internal migration are also executed as bachelor's degree, master's degree and doctoral theses by academic circles. Such population movements are carried out in conjunction with the economic issues in labor economics, economics, business administration and public administration departments of Faculty of Economics and Administrative Sciences. Also, the geographical distribution of population

${ }^{2}$ Infos given in this title were gathered from the internet site of relevant events. 
movements is examined in geography departments. Various studies were conducted especially on the rural aspect of rural migrations and its agricultural effects in Agricultural Economics department of Agricultural Faculties.

\section{Conclusion and Discussion}

Humans changed the place they lived throughout the history for various reasons. This change caused the culture and civilizations to move and develop as well. Migrations from rural to urban especially in developing countries are accepted as an important indicator which puts forth the economic and social developments in these countries.

Internal migrations that took place especially after 1950s in Turkey put forward the most crucial reason and results in the change the country went through in economic and social aspects. Examining and investigation such population movements help immensely in setting forth the economic and social developments in these countries.

Who helped significantly the internal migration studies in Turkey were for starters academic circles and their NGOs. Choosing correctly the aim, material and methods of such studies will cause the social events to be explained clearly. Also it's a fact that there are various deficiencies, most common one would be data deficiency, in examining and investigating especially internal migrations in countries such as Turkey. In overcoming these, having various scientific disciplines more active should be regarded as a must.

\section{Referencess}

[1]. Asrafhul Alam., Khalil Momtaj Bintay., (2012). Migration and Inter-Dependence, Sustainable Urbanism in the Pearl River Delta Region, South China, Journal of Social and Development Sciences, 3(3), pp.99-107.

[2]. Bilgili, Özge., Weyel, Silja., (2009). Migration in Morocco: History, Current Trends and Future Prospects, Paper Series: Migration and Development Country Profiles, Maastricht Graduate School of Governance, Ministry of Foregin Affairs.

[3]. Çağlayan, Savaş., (2006). Göç Kuramları, Göç ve Göçmen İlişskisi, Muğla Üniversitesi Sosyal Bilimler Enstitüsü Dergisi, Sayı: 17.

[4]. Çelik, Fatih., (2007). Türkiye'de İç Göçler: 1980-2000. Erciyes Üniversitesi Sosyal Bilimler Enstitüsü Dergisi, Sayı:22, 87-109.

[5]. Düztepe, Şerafettin., (2004). Araştırmalarda Bilimsel Yöntemin Kullanılması ve Araştırmanın Temel Aşamaları. Havacılık ve Uzay Teknolojileri Dergisi, 1(3), 49-53.

[6]. Güran, Tevfik., (2009). İktisat Tarihi. Der Yayınları, 201s.

[7]. Gürbüz, Mehmet., Karabulut, Murat., (2008). Kırsal Göçler İle Sosyo-Ekonomik Özellikler Arasındaki İlişkilerin Analizi. Türk Coğrafya Dergisi, sayı: 50, 37-60.

[8]. Güreşci, Ertuğrul., Yurttaş, Ziya., (2008). Kırsal Göçün Nedenleri ve Tarıma Etkileri Üzerine Bir Araştırma: Erzurum İli İspir İlçesi Kırık Bucağı Örneği. Tarım Ekonomisi Dergisi, 14(2), 47-54.

[9]. Güreşci, Ertuğrul., (2009). Kırsal Göç ve Tarım Politikası Arasındaki İlişki. Muğla Üniversitesi Sosyal Bilimler Enstitüsü Dergisi, Say1:22, 51-67.

[10]. Güreşci, Ertuğrul; (2010). Türkiye’de Kentten - Köye Göç Olgusu. Doğuş Üniversitesi Dergisi, 11(1), 77-86.

[11]. Güreşci, Ertuğrul., (2011). Türkiye'de Köyden Kente Göç ve Düşündürdükleri. Sosyoekonomi Özel Sayı 2011-MI, $125-135$.

[12]. Güreşci, Ertuğrul., (2012). Türkiye'nin Köyden Kente Göç Sorunu. Gümüşhane Üniversitesi Sosyal Bilimler Elektronik Dergisi, Say1:6, 41-55.

[13]. IOM., (2013). International Organization for Migration, Migration and History, Section 1.3.

[14]. Kundu, Amitabh., (2009). Urbanisation and Migration. An Analiysis of Trend, Pattern and Policies in Asia. Human Development Research Paper 2009/16, p55.

[15]. Kurt, Hacı., (2006). Göç Eğilimleri ve Olası Etkileri. Yönetim Bilimleri Dergisi, 4(1), 148-178.

[16]. National Geopraphic., (2005). Marcopolo Xpeditions, Human Migration Guide (6-8).

[17]. Ongun, M.Tuba., (2009). Sanayileşme ve Uluslararası Ekonomik İlişkiler. Gazi Kitabevi, 161s.

[18]. Özdamar, Kazım., Odabaşı, Yavuz; Hoşcan, Yaşar; Bir, Ali Atı; İftar, Gönül; Özmen, Ahmet; Uzuner, Yıldız; (1999). Sosyal Bilimlerde Araştırma Yöntemleri. T.C. Anadolu Üniversitesi Yayınları No: 1081, Açıöğretim Fakültesi Yayınları No: 601; 10s.

[19]. Özdemir, Hakan., (2012). Türkiye'de İç Göçler Üzerine Genel Bir Değerlendirme. Akademik Bakış Dergisi, Sayı:30, 1 -18.

[20]. Park, Robert.E., (1928). Human Migration and Marginal Man. The American Journal of Sociology, Volume: 33, No:6, $881-893$.

[21]. Sağlam, Serdar., (2006). Türkiye'de İç Göç Olgusu ve Kentleşme. Türkiyat Araştırmaları, Hacettepe Üniversitesi Türkiyat Araştırmaları Enstitüsü, Sayı: 5, 32-44.

[22]. Saraçoğlu, Cenk., (2013). Türkiye'de Göç Çalışmalarında $1980 \quad$ Sonrası Paradigma Değişimi. http://www.kongrekaraburun.org/eski/tam_metinler_2010/b_3/05_Cenk_Saracoglu.pdf (Erişim Tarihi: 29.01.2013).

[23]. Smith, Michale E., (2009). Centenary Paper V. Gordon Childe and the Urban Revolution: a Historical Perspective on a Revolution in UrbanStudies. TPR, 80(1), pp. 4-29.

[24]. Şenel, Alaadin., (1982). İlkel Topluluktan Uygar Topluma Geçiş Aşamasında Toplumsal Düşünsel Yapıların Etkileşimi. Ankara Üniversitesi Siyasal Bilgiler Fakültesi Yayınları No: 504, 324s, Ankara.

[25]. Topbaş, Ferhat., Tanrı̈̈ver, Banu., (2008). Türkiye'de İç Göç Akımları Üzerine Bir Çalışma: Lowry Hipotezi. 2. Ulusal İktisat Kongresi, 20-22 Şubat 2008, İzmir, Türkiye.

[26]. TÜİK., (2012). Göç İstatistikleri. Türkiye İstatistik Kurumu, Ankara.

[27]. Yavuz, Fahri., Yavuz, F., Aksoy, A., Topçu, Y. ve Erem, T., (2004). Kuzeydoğu Anadolu Bölgesi'nde Kırsal Alandan Göç Etme Eğilimini Etkileyen Faktörlerin Analizi. Türkiye VI. Tarım Ekonomisi Kongresi, Tokat. 